\title{
Sound-Color and Phono-Semantic Analysis of Literary Poetic Text by Synesthets
}

\section{Особенности звуко-цветового и фоносемантического анализа поэтических текстов синестетами}

Mariya Elivanova

Ph.D. in Philology,

Assistant Professor

\section{Мария Еливанова}

кандидат филологических наук, доцент

E-mail: melivanova@yandex.ru

orcid.org/0000-0002-9828-7470

Herzen State Pedagogical

University of Russia,

Saint Petersburg, Department

of Language and

Literary Child Development

$\triangle 48$, Embankment of the river

Moika, Saint-Petersburg, 191186
Российский государственный педагогический университет им. А.И. Гериена, кафедра языкового и литературного образования ребенка

$\checkmark$ Набережная р. Мойки, 48, Санкт-Петербург, 191186

Original manuscript received March 03, 2018

Revised manuscript accepted October 02, 2018

\section{ABSTRACT}

The article is concerned with investigating the problem of synesthesia that manifests itself in the fact that stimulation in one sensory-based system or cognitive system that leads to automatic reaction in another one.

This article is the continuation of the research published in the previous one (Еливанова, Семушина, 2017) in which we described statistically significant sound / alphabet letters-color and words-color correlations typical for synesthets. The aim of the next stage was to research synesthets' capability of sound-color and phono-semantic analysis of a poetic text. Phonosemantics is a Russian branch of linguistic, its subject matter is sounds that create images.

12 synesthets took part in the research at the first stage. We offered them to analyze a piece of poetry "Grasshopper» by V. Hlebnikov (В. Хлебников). 
We revealed that synesthets have different capabilities of sound-color analysis of a literary poetic text that manifest individual and typological specifics of sound-color capability. 2 (16.7\%) of examined respondents who have artistic type of higher nervous function with its high potential color-sound language system are good at intuitive phono-semantic analysis of a poetic text.

Then we offered 3 curated synesthets extracts of poetry by А. Блок, A. Белый and Edgar Allan Poe (in original and in the translation by 3 different Russian poets).

Analysis showed that individual method of synesthets partly coincides with the method of automatical analysis that is based on letter occurrence frequency in a text. Synesthets do not necessarily feel colors of frequent letters / sounds that have not equal meaning for the color perception of words and the text as a whole.

Synesthesia specifics combined with emotional image reflection of colorsound of analyzed texts let synesthets intuitively decode motivation coded with the help of phonetic means of language in the text by the authors of poems.

In spite of individual variability of synesthetic perception of a text there is phono-semantic general invariability that is caused by imaginative comprehension of sound-color of poetic texts.

Key words: synesthesia, synesthet, sound-color capability, phono-semantic, sinesthemia, letter, sound, color.

\section{Вступление}

Исследование имело целью выяснить способности синестетов (людей, у которых раздражение в одной сенсорной или когнитивной системе ведет к автоматическому непроизвольному отклику в другой сенсорной системе - (Cytowich, 2002; García-Matos \& Torner, 2015)) к звуко-цветовому и фоносемантическому анализу поэтических текстов.

Фоносемантика - направление лингвистики, предметом которого является изучение звукоизобразительной системы языка. Оно основано на том, что звуки речи могут нести в себе свой особый самостоятельный смысл. У истоков этой науки о языке стоят создатель теории фонетического значения А.П. Журавлёв (1974) и основатель звукосимволизма С.В. Воронин (1982). Главным её принципом является принцип непроизвольности языкового знака.

А.П. Журавлёв $(1974 ; 1991)$ производил компьютерный звукоцветовой и фоносемантический анализ стихотворений на основе разработанной им методики с учётом средних оценок цвета 
Sound-Color and Phono-Semantic Analysis of Literary Poetic Text...

гласных и фонетического значения «звукобукв», а также отклонения их частоты от нормы в текстах. Интерес к звуко-цветовому и фоносемантическому анализу поэтических текстов в последнем десятилетии возрос, появились диссертационные исследования с использованием компьютерного метода (Прокофьева, 2009; Ищенко, 2009). Адаптировав методику и используя статистически значимые данные о цвете «графонов», Л.П. Прокофьева подвергла автоматическому анализу звуко-цветовые соответствия множества поэтических текстов на русском и английском языках и сопоставила полученные результаты с результатами аудиторского анализа этих текстов гимназистами. Специальных исследований звукоцвета и звуковой символики поэтических текстов с русскоязычными информантами-синестетами до настоящего времени не проводилось.

В западной традиции в исследовании синестезии преобладает нейрофеноменологический подход (см, например, (Cytowich, 2002; Hubbard \& Ramachandran, 2005)). Стихотворные тексты также становились предметом исследования, например, в (Dittmar, 2007). Однако авторы работ рассматривали, какое отражение феномен синестезии поэтов находит в их творчестве, и не ставили своей задачей исследование того, как воспринимают тексты синестеты, читающие или слушающие стихотворные строки.

\section{Методы исследования}

Исследование выполнено с участием двенадцати синестетов, которых мы благодарим за сотрудничество. Респондентам предлагался для анализа ряд поэтических текстов. Задача состояла в том, чтобы, читая текст вслух и не вдумываясь в смысл слов, составить общее представление о цвете текста и роли в нём цвета звуков/букв, а также о смысле звукоцвета стихотворения и о вызванных им образных смысловых ассоциациях.

\section{Обсуждение результатов}

Проведенное нами экспериментальное исследование включало в себя два этапа. На первом этапе всем двенадцати респондентам было предложено для анализа стихотворение В. Хлебникова «Кузнечик».

В. Хлебников: «Крыльишкуя золотописьмом / Тончайших жил, / Кузнечик в кузов пуза уложил / Прибрежных много трав 
и вер. / «Пинь, пинь, пинь!» - тарарахнул зинзивер. / О, лебедиво! О, озари!» («Кузнечик»).

Сделанный

респондентами

звукоцветовой

И

фоносемантический анализ стихотворений разных авторов показал следующие результаты.

Светлана Желязко. Графемно-фонемный синестет. Всё стихотворение золотое, как золото и буква 3, её здесь необычно много. Много светло-коричневого $\mathrm{K}$, серого $\mathrm{T}$ и тёмнокоричневого Р. ПИНЬ-ПИНЬ не в цветовой гамме, оно тёмно-синее, как П, и выпадает из контекста. ЛЕБЕДИВО с ярким зеленоватоголубым Л тоже не в тему, без него и без ПИНЬ было бы намного гармоничнее.

Александр Волков. Фонемный синестет. Салатовые оттенки по всему стихотворению. По строчкам есть всплески коричневого, но в итоге все переходит в различные оттенки зелёного. Преобладающие звуки: И - жёлто-зелёный с золотистым отливом, Ж - болотный, 3 светло-зелёный, К - красно-коричневый. Смысла цвета и звучания текста не понимает.

Ольга Турьева. Графемно-фонемный синестет. Очень много буквы 3, поэтому ассоциация со звуком работающей бензопилы. Сочетание ЖИ, которое тоже несколько раз присутствует, имеет цвет ржавого железа, поэтому «железные» стихи дают ощущение лязга и скрежета на зубах при чтении.

Евгения Громова. Графемно-фонемный синестет. Если просто читать стихотворение вслух, рисуются образы летнего дня, травы, крыльев стрекозы. Цвет букв на втором плане. Если заучивать, то строчки имеют цвет первого слова (первой его буквы): К - синий, Т - оранжево-жёлтый, П - синий. В последней строчке белое О подтягивает жёлтый цвет Л из ЛЕБЕДИВО, поэтому строка в целом белая и жёлтая. Цвет строк не несёт образной информации.

Марина Дубровская. Графемно-фонемный синестет. Очень много букв участвует, поэтому текст сливается в сероватый цвет, который отливает синим от букв К в первой половине текста и коричневым из-за П и Т во второй. Последняя строка белого цвета из-за четырёх белых букв О.

Эдуард Михалёв. Фонемный синестет. «Не получается не вдумываться совсем, вместо этого слова начинают представляться сложенными из объёмных букв, висящих в пустоте и 
Sound-Color and Phono-Semantic Analysis of Literary Poetic Text...

воспринимаемых не как набор букв, а как соединение слогов, иногда не совпадающих с фонетическими... Общее восприятие стихотворения со временем поменялось от однообразного лёгкого белого дымка со слабым синим или зелёным оттенком (белый холодного оттенка, если можно так сказать) вначале до более плотной субстанции, похожей на крупноячеистую пену с различимой блочной структурой, где ячейки переливаются разными цветами в разной последовательности и с разной длиной цикла бессмысленный образ бессмысленного стихотворения». По строкам и по составляющим их словам описал цветную модель возникшего в сознании образа.

Анна Морозова. Графемно-фонемный синестет. Общий цвет текста стихотворения состоит из цветов самых часто встречающихся букв: коричневого, жёлтого, синего.

Наталья T. Фонемный синестет. Много темных оттенков зеленого, коричневого и чёрного, общий цветовой тон тёмный. Светлое только розовое слово ЛЕБЕДИВО.

Софья Ковтун. Графемно-фонемный синестет. Чёрнокоричневые, темно-синие, зелёные, малиновые цвета больше проявились, стихотворение в целом тёмное.

Танита Гриценко. Графемно-фонемный синестет. Первая строка в основном золотистая, во второй есть белый, чёрный, желтый, оранжевый, в третьей - коричневый, четвёртая строка коричневатозеленая. ПИНЬ-ПИНЬ коричнево-чёрное, ТАРАРАХНУЛ - белое с коричневым и чёрным, ЗИНЗИВЕР - коричневое с оранжевым.

Даша Дубовая. Графемно-фонемный синестет. Больше всего жёлтых, зелёных, розовых цветов в тексте.

Мама Пахомова. Графемный синестет. При чтении буквы чёрные. Если задуматься об общем цвете текста, то в нём есть серый, оранжевый, коричневый, синий цвета.

В. Хлебников фонетическими средствами изобразил в стихотворении Кузнечика зелёного Tettigonia viridissima, брачная песня которого состоит из однообразных стрекочущих звуков. Другой художественный образ - птичка синица большая Parus major, которую в местных диалектах на севере России называют зинзивером или кузнечиком за многократное повторение коленца весенней песенки «зин-зи-пи». Крик тревоги - «Пинь-пинь тарарах». Звукоцветовые ассоциации у всех синестетов разные. На восприятии 
цвета стихотворения сказались индивидуальные особенности синестезии. О том, что синестезия может быть выражена в разной степени (Deroy \& Spence, 2013) и имеет индивидуальные особенности и вариабельна см., например, (Brogaard, 2014).

Для дальнейшего исследования отобраны три респондента. А. Волков - фонемный синестет с мыслительным типом ВНД (по И.П. Павлову). О. Турьева и С. Желязко - графемно-фонемные синестеты с художественным типом ВНД, способные к восприятию фонетических смысловых значений. С. Желязко сообщила, что оторвать звук и цвет от смысла не может и её восприятие идёт по формуле ЗВУК + ЦВЕТ + СМЫСЛ = ЕДИНОЕ ЦЕЛОЕ.

А. Блок: «Белой ночью месяч красный / Пропльвает в синеве. / Бродит призрачно-прекрасный, / Отражается в Неве. / Мне провидится и снится / Исполненье тайных дум. / В вас ли доброе таится, / Красный месяц, тихий шум?..»

Светлана Желязко. Стихотворение динамичное, цветное. Преобладает синий цвет. То, что слово КРАСНЫЙ повторяется два раза, не задаёт стихам красный тон. Вторая строка с тремя синими словами подряд (синие В и П, слово СИНИЙ) подавляет всё остальное. К концу синий цвет подкрепляется двумя синими словами «В ВАС».

Ольга Турьева. Стихотворение связано с чем-то магическим, темным, неизведанным. Оно как зеркало в сказке про Алису из Зазеркалья: тронешь его рукой, а она в него погружается. Много желто-зеленого цвета, так как такие буквы присутствуют почти в каждом слове. Например, в слове БЕЛОЙ есть немного зелёного и жёлтый, НОЧЬЮ - темно-синий, жёлтый. Светло-жёлтая буква О сильно влияет на цвет слов, как и гласные Е, У, А, Ы, Э, Я. Слово МЕСЯЦ зеленоватого оттенка, переходящего в синий.

Александр Волков. Стихотворение бело-голубое, на последней строчке скачок в красно-коричневый. Преобладают цвета Б (белоголубой), Н (синий), К (красно-коричневый) и Т (коричневый).

У А. Блока белый цвет, наряду с символикой чистоты и совершенства, несёт также символику отчуждения, страдания, мертвенности, тоски. Эти настроения усиливает синий цвет, который в его поэзии является цветом сумерек, тайны, холода и печали. Красный у русских поэтов-символистов является цветом губившего Россию хаоса. Но у Блока красный - это цвет жизненной энергии. 
Sound-Color and Phono-Semantic Analysis of Literary Poetic Text...

Можно считать, что все респонденты по-своему уловили звукоцветовые коды стихотворения. Однако значение их смыслу придала только О. Турьева. Но и С. Желязко написала о «борьбе» красного и преобладающего синего цвета в звукоцвете стихотворения.

А. Блок: "Ветер хрипит на мосту меж столбами, / Чёрная нить под снегами гудёт. / Чудо ползёт под моими санями, / Чудо мне сверху поёт и поёт. / Всё мне певуче, тяжко и трудно, / Песни твои, и снега, и костры, / Чудо, я сплю, я устал непробудно... / Чудо, ложись в снеговые бугры!»

Светлана Желязко. Стихотворение очень тёмное. Тёмнокоричневые Ч и Р, чёрное Д и тёмно-синее П очень часты. Очень тёмное слово ХРИПИТ.

Ольга Турьева. В стихотворении преобладают буквы тёмных оттенков. По цвету оно тёмное, с включениями светлых гласных. По образному смыслу похоже на узкий тёмный колодец. Чем ниже спускаешься, тем темнее.

Александр Волков. Цвет стихотворения от почти чёрного тёмно-серого к бежевому. В цветовой гамме преобладают темносерый X, темный коричневый Ч, бежевый П.

В стихотворении А. Блока предчувствия революции 1905 года в России символизируются чёрным цветом, который означает неоднозначность. «Чёрное чудо» - это «тайна, покрытая мраком». Тёмный колорит у синестетов отвечает мрачно-тревожному настроению поэта.

А. Блок: «На гладях бесконечных вод, / Закатом в пурпур облаченных, / Она вещуает и поёт, / Не в силах крыл поднять смятенных... / Вещуает иго зльхх татар, / Вещуает казней ряд кровавых, / И трус, и голод, и пожар, / Злодеев силу, гибель правых... / Предвечнылм ужасом объят, / Прекраснылй лик горит любовью, / Но вещей правдою звучат / Уста, запекииеся кровью.» («Гамаюн - птица вещзая»).

Светлана Желязко. Очень цветное стихотворение, в нём много зелёного (в словах Н и И зелёные) и синего (П и В). Эти два цвета преобладающие.

Ольга Турьева. В стихотворении фразы чёткие, как барабанная дробь. Ассоциируется с непогодой перед грозой. Часто встречается бесцветная буква Л, которая видится как прозрачная вода, окрашенная соседними буквами. Первая половина стихотворения 
более светлого цвета из-за белого А в словах ГЛАДЯХ, ЗАКАТОМ, ОБЛАЧЕННЫХ, ВЕЩАЕТ. Со слова КРЫЛ текст темнеет от чёрных Ы, И, Д в словах СМЯТЕННЫХ, ИГО, ЗЛЫХ, РЯД и других. Иногда среди черноты мелькает светло-жёлтый цвет О. Со слова ПРАВЫХ текст светлеет от слов ГОРИТ, ЛЮБОВЬЮ, ПРАВДОЮ и других.

Александр Волков. Цвет стихотворения переходит от синего в зелёный, в конце он светло-коричневый. В цвете преобладают синее Н, зелёное В, жёлто-зелёное И и коричневое Т.

А. Блок словесно описал свои впечатления от картины В. Васнецова, на которой изображена вещая птица с красивым женским лицом, чёрными туловищем и крыльями, синими маховыми и хвостовыми перьями и рыжим надхвостьем. Птица вещает грядущую бурю. Фон красный вверху и внизу и охристый с зелёным в середине картины.

А.П. Журавлёв в своей книге «Звук и смысл» отметил: «Расчёт звукоцвета на компьютере показал, что в стихотворении среди гласных наиболее заметно доминируют красные А и Я, тёмный Ы и тёмно-зелёный У». Никто из синестетов не обнаружил красного цвета, который фонетически закодирован поэтом. У О. Турьевой цвет А белый, Я - тёмно-синий; у А. Волкова А - белый, Я красноватый. У С. Желязко А и Я красные, но этот цвет она тоже не заметила в связи с особенностями синестезии. В восприятии цвета слов у неё особую роль играют первая буква слова и согласные. В стихотворении на слух красного вообще не видит, кроме красного слова КРОВЬЮ (оно имеет цвет денотата). Когда читает текст, красная буква А мелькает, но не выделяется.

А. Бельй: «Упал на землю солниа краснылй круг, / И над землёй, стремительно блистая, / Приподнялась зеркальность золотая / И в пятнах пепла тлела. / Всё вокруг вдруг стало: и - туманисто, и серо... / Стеклянно зеленеет бирюза, / И яркая заяснилась слеза - / Алмазная, алмазная Венера.» (Звезда).

Светлана Желязко. Общий цвет прозрачно-голубо-золотой. СЛова БЛИСТАЯ, ЗЕРКАЛЬНОСТЬ, СТЕКЛЯННО и СЛЕЗА прозрачные, много синих П и В, из-за прозрачности слов рядом они становятся здесь голубыми. Да ещё голубое слово ВЕНЕРА. Золотой цвет даёт частый звук 3 и слово ЗОЛОТО. 
Sound-Color and Phono-Semantic Analysis of Literary Poetic Text...

Александр Волков. Стихотворение всё в вертикальную коричневую полоску (из-за красноватых М и Я) на зеленом фоне и в конце светлеет из-за гласного А. Преобладает цвет 3 (светлозелёный), М (красный), В (зелёный).

Ольга Турьева. В первой половине стихотворения почти в каждом слове есть буквы 3 и С, они обе «железные», только 3 с жёлтым оттенком, а С с металлическим. Но они не окрашивают стихи, а просто «прошивают» их. Ассоциация у меня почему-то с вязанным крупной вязкой свитером или джемпером кирпичного цвета из-за слова УПАЛ. Буква У очень сильно влияет на первую строчку, придавая ей кирпично-красный цвет. Слова ЗЕРКАЛЬНОСТЬ ЗОЛОТАЯ жёЛто-золотого цвета. Слово ЗОЛОТО очень правильно подобрано по цвету металла. А следующие по порядку два предложения серого цвета. Слово ПЕПЕЛ тоже очень подходит по цвету к самому пеплу. Концовка немного отдает зелёным и также «прошита» 3 и С. Слово ВЕНЕРА видится краснокоричневым с зеленым, очень яркие цвета и красивое их сочетание. А вот слово ЗЕМЛЯ - это смесь железа и тьмы.

Стихотворение А. Белого - это символическая апология мифа в вечности Вселенной, мрачный образ Земли (символика обыденного) и возвышенный образ Венеры (символ любви, красоты и творческих способностей). В своих ассоциациях О. Турьева уловила двойственность, а С. Желязко восприняла только одну прекрасную, идеальную сторону стихотворения.

А. Бельй: "Солнием сердие зажжено. / Солниее вечному стремительность. / Солние - вечное окно / в золотую ослепительность. / Роза в золоте кудрей. / Роза нежно кольхается. / В розах золото лучей / краснылм жаром разливается. / В сердие бедном много зла / сожжено и перемолото. / Наши души - зеркала, / отражающие золото.» (Солнще).

Светлана Желязко. Стихотворение жёлто-золотое, жужжащее, как жук или оса, но доброе. Слово СОЛНЦЕ жёлтое, много жёлтой C, а 3 - золотое. В слове РОЗА коричневое Р и золотое 3 идеальны для цветовой гаммы, но троекратно повторённое само слово РОЗА розовое, оно не в тему.

Александр Волков. Жёлто-зелёное, в конце переходит в синий с оттенком розового. Преобладают С (белый, светлые жёлтый и зелёный), Р (жёлтый), 3 (светло-зелёный) и Н (синий). Светлый 
оттенок С здесь изменяется под влиянием соседних звуков и преобладающего их цвета.

Ольга Турьева. Стихотворение будто бы состоит из металла (буква С металлического цвета). Возникает ощущение, что, когда автор писал его, он морщился от боли и, сжимая зубы, издавал звук С при вдохе, как бывает, когда терпишь боль. СОЛНЦЕМ СЕРДЦЕ ЗАЖЖЕНО - строка жёлтая, а по ощущениям - инеем покрытая, замёрзло сердце. Общий цвет тоже жёлтый, всё блестит, как золотое кольцо, так как очень много буквы О. Ассоциация цвета в этом стихотворении связана с большим жёлтым пламенем.

А. Белый вложил в стихотворение символический смысл стремления к Солнцу, до которого невозможно добраться, желание уйти от злободневной обыденности. Солнце - это созидательный символ, средоточие интуитивного знания, божественный символ борьбы с мраком. С символом Розы связаны тайна, необходимая при посвящении тишина, а также любовь и радость. Роза может выступать и как символ солнца и поэтического вдохновения. Общее впечатление от стихотворения у респондентов светлое. С. Желязко в своём восприятии цвета заметила темы Солнца и Розы, у неё возникло чувство диссонантности. О. Турьева обнаружила по цвету только золотой мотив Солнца. Негативную мотивировку несёт в себе в её случае фонема С.

Эд. По «Ворон». Последняя строфа стихотворения на английском языке была предложена для анализа С. Желязко и О. Турьевой. О. Турьевой затем был дан дословный перевод на русский язык и три стихотворных перевода русских поэтов. Мы попросили её определить, насколько каждый перевод совпадает по звуку и цвету с английским оригиналом.

Светлана Желязко: "- And the Raven, never flitting, still is sitting, still is sitting. / - D, R - черный и темно-коричневый, потом есть яркие цвета - N, F, S, но они почти совсем не видны, я думаю, из-за коротких и резких слогов вокруг твердых серых Т, И; шипение $\mathrm{S}$ скорее дает не жёлтый цвет, а погружает в транс, как шипение змеи... - On the pallid bust of Pallas just above my chamber door; / - Т, Р (здесь звук вроде синий, но форма букв тёмно-коричневая, это же русская Р, так что что-то очень тёмное в любом случае). В, Р, $\mathrm{B}, \mathrm{M}, \mathrm{B}, \mathrm{D}$ - цвета серый, коричнево-синий, темный коричневый, бордовый, тёмный коричневый, черный. Вообще, В - очень 
драматичная буква. Как и D... В звучании с русским произношением звуков все идеально. - And his eyes have all the seeming of a demon's that is dreaming, / - Чуть-чуть видны A, E, T, D, R, G - красный, лиловый, серый, черный, темно-коричневый, черный. - And the lamp-light o'er him streaming throws his shadow on the floor; / And my soul from out that shadow that lies floating on the floor / Shall be lifted - nevermore! - Тут цвет вообе не имеет значения, так как всё уже давно стемнело. Но вот ещё эта барабанность, как шаги с эхо в темноте... Какие уж там цвета!».

Ольга Турьева прослушала стихотворение на английском языке и сообщила, что первая строка по цвету тёмно-синяя. В ней много тёмных согласных, в сочетании с чёрным И они дают тёмносиний цвет. Вторая и третья строка светлых тонов из-за часто встречающейся белой буквы А в словах. Четвёртая и пятые строчки светло-серого цвета, похожего на тусклый свет, они пушистые, воздушные, так как в них есть Ф. Стихотворение кажется округлым, оно напоминает пустую стеклянную банку.

Перевод в прозе наиболее близок к английскому тексту по цветовой окраске. Первая строка тёмного оттенка, начало второй строки светлеет, слово ПАЛЛАДА очень светлое из-за удвоенного белого А и водянисто-прозрачной Л, которая также светлеет рядом с А. Слово ГЛАЗА тоже имеет светлый оттенок за счёт удвоенного А. Остальная часть текста серого оттенка из-за часто встречающихся серых П, К и Ш. Смысл звука и цвета ассоциирован с лишней тканью, которую надо подогнуть и подшить...

К. Бальмонт: «И сидит, сидит зловещиий Ворон чёрный, Ворон вещий, / С бюста бледного Паллады не умчится никуда. / Он глядит, уединённый, точно Демон полусонный, / Свет струится, тень ложится, - на полу дрожит всегда. / И душа моя из тени, что волнуется всегда, / Не восстанет - никогда!» Перевод тёмных тонов, можно сказать, чёрного цвета, с редкими вкраплениями светлых тонов благодаря гласным. Стихотворение ассоциируется с тёмным углом в комнате.

Д. Мережковский: «И сидит, сидит с тех пор он / там, над дверью чёрный Ворон, / С бюста бледного Палладь / не исчезнет никуда. / У него такие очи, / как у Злого Духа ночи, / Сном объятого; и лампа / тень бросает. Навсегда / K этой тени чёрной птиць / пригвождённый навсегда, - / Не воспрянет дух 
мой - / никогда!» Первая строчка тёмных тонов, к концу светлеет, вторая строка подхватывает этот светлый тон и к концу становится тёмной, третья строка повторяет по тональности первую, её тёмный цвет переходит на четвёртую строку. Пятая строка тёмная, далее постепенно светлеет к концу шестой, и так всё повторяется вплоть до восьмой строки. Кроме светлых и тёмных оттенков, других цветов как бы и нет в этом стихотворении. Оно ассоциируется с электрокардиограммой.

В. Брюсов: «И как будто с бюстом слит он, всё сидит он, всё сидит он, / Там, над входом. Ворон чёрный, с бельмм бюстом слит всегда! / Светом лампь озарённый, смотрит, словно демон сонный. / Тень ложится удлиненно, на полу лежит года, - / И душе не встать из тени, пусть идут, идут года, - / Знаю, больше никогда!» Первая строка практически чёрного цвета. Этот цвет светлеет к концу второй строки, с середины третьей снова темнеет и далее до конца сохраняется тёмный оттенок. Часто встречается чёрный Д, чёрный И с темными согласными. Ассоциация с переводом как с чем-то неуместным, как коленки сзади, неудобное что-то.

С. Желязко проанализировала текст Эд. По с опорой не только на свою синестезию и владение английским, но в более широком плане, с позиций синестемии (соощущения + соэмоции, по С.В. Воронину). О. Турьева также в английском тексте Эд. По уловила фонетически мотивированное чувство безысходности и пустоты (символ пустой банки). Мрачное настроение она обнаружила и во всех русских переводах. Можно предположить, что различия её восприятие английского и русских поэтических текстов зависят от разных звукоцветовых систем языка и от авторских языковых особенностей.

\section{Выводы}

Синестеты имеют неодинаковые возможности звуко-цветового анализа текстов, обусловленные индивидуальными особенностями синестезии. Их субъективный метод не вполне совпадает с методикой автоматического анализа, основанного на выявлении повышенной частоты букв в тексте.

Отдельные синестеты проявили свою способность к интуитивному фоносемантическому анализу стихотворений. 
Sound-Color and Phono-Semantic Analysis of Literary Poetic Text...

При индивидуальной вариативности звуко-цветового восприятия фоносемантическая инвариантная универсальность создаётся за счёт синестемии и образного осмысления звукоцвета поэтических текстов.

\section{Литература}

Воронин, С.В. Основы фоносемантики. Ленинград, 1982. 234 с.

Журавлёв, А.П. Фонетическое значение. Ленинград : Изд. ЛГУ, 1974. 159 с.

Журавлёв, А.П. Звук и смысл. Москва : Просвещение, 1991. С. 117.

Еливанова, М.А., Семушина, В.А. Звуко-цветовые соответствия алфавита и слов при синестезии. Психолінгвістика. Психолингвистика. Psycholinguistics. 2017. Вып. 22. С. 28-49. Режим доступа: http://psychling.phdpu.edu.ua/index.php/ua/ arkhiv/11-arkhiv/99-22-2017. doi: 10.5281/zenodo.1069533

Ищенко, Д.С. Фоносемантические и цветофоносемантические художественные ассоциации в поэтической речи (на материале творчества В.Я. Брюсова) : автореф. дисс. канд. филол. наук. Ставрополь, 2009. 22 с. [Электронный ресурс]. Режим доступа: new-disser.ru' avtoreferats/01004630766.pdf

Прокофьева, Л.П. Звуко-цветовая ассоциативность в языковом сознании: универсальное, национальное, индивидуальное : автореф. дисс. докт. филол. наук. Саратов, 2009. 47 с. [Электронный ресурс]. Режим доступа: new-disser. ru' avtoreferats/01004652771.pdf

Brogaard, B. (2014). Varieties of Synesthetic Experience. In: Brown R. (eds) Consciousness Inside and Out: Phenomenology, Neuroscience, and the Nature of Experience. Studies in Brain and Mind, 6, 409-412. doi.org/10.1007/978-94-0076001-1 28

Cytowich, Richard, E. (2002). Synesthesia: a Union of the Senses. Cambrige, MIT Press.

Deroy, O., \& Spence, C. (2013). Why we are not all synesthetes (not even weakly so). Psychon Bull Rev, 20, 643. doi.org/10.3758/s13423-013-0387-2

Dittmar, A. (Ed.), (2007). Synästhesien. Roter Faden durchs Leben? Essen: Verlag Die Blaue Eule.

García-Matos, M., \& Torner, L. (2015). Sensing. In: The Wonders of Light. Cambridge University Press, 121-129. doi.org/10.1017/CBO9781316151075.018

Hubbard, Edward M., \& Ramachandran, V.S. (2005). Neurocognitive mechanisms of synesthesia. Neuron, 48(3), 509-20. Retrieved from: http://www.cell.com/neuron/ fulltext/S0896-6273(05)00835-4

\section{References}

Voronin, S.V. (1982). Osnovy phonosemantiki [Principles of Phono-semantic]. Leningrad [in Russian].

Zhuravlev, A.P. (1974). Phoneticheskoe znachenie [Phonetic Meaning]. Leningrad [in Russian].

Zhuravlev, A.P. (1991). Zvuk i smysl [Sound and Meaning]. Moscow: Prosveschenie [in Russian].

Elivanova, M.A., \& Semushina, V.A. (2017). Zvuco-tsvetoviie sootvetstviia alfavita i slov pri sinestezii [Synesthetic sound-color capability for alphabetic letters and 
words]. Psiholingvistika - Psycholinguistics, 22, 18-49. Retrieved from: http:// psychling.phdpu.edu.ua/index.php/ua/arkhiv/11-arkhiv/99-22-2017 doi: 10.5281/ zenodo.1069533 [in Russian].

Ishchenko, D.S. (2009). Fonosemanticheskie i tsetofonosemanticheskie hudozhestvenniie assotsiathii v poeticheskoi rechi (na materiale tvorchestva V.Y. Brusova) [Phonosemantic and color-phono-semantic art associations in poetic speech (in case study of V. Brusov's creation)]. Extended abstract of candidate's thesis. Stavropol. Retrieved from: new-disser.ru'_avtoreferats/01004630766.pdf [in Russian].

Prokofyeva, L.P. (2009). Svuco-tsetovaia assotsiativnost V iazikovom siznanii: universalnoie, nazionalnoie, individualnoie [Sound-colors Associativity in Linguistic Consciousness: Universal, National, Individual]. Extended abstract of Doctor's thesis. Saratov. Retrieved from: new-disser.ru' avtoreferats/01004652771.pdf

Brogaard, B. (2014). Varieties of Synesthetic Experience. In: Brown R. (eds) Consciousness Inside and Out: Phenomenology, Neuroscience, and the Nature of Experience. Studies in Brain and Mind, 6, 409-412. doi.org/10.1007/978-94-0076001-1 28

Cytowich, Richard, E. (2002). Synesthesia: a Union of the Senses. Cambrige, MIT Press.

Deroy, O., \& Spence, C. (2013). Why we are not all synesthetes (not even weakly so). Psychon Bull Rev, 20, 643. doi.org/10.3758/s13423-013-0387-2

Dittmar, A. (Ed.), (2007). Synästhesien. Roter Faden durchs Leben? Essen: Verlag Die Blaue Eule.

García-Matos, M., \& Torner, L. (2015). Sensing. In: The Wonders of Light. Cambridge University Press, 121-129. doi.org/10.1017/CBO9781316151075.018

Hubbard, Edward M., \& Ramachandran, V.S. (2005). Neurocognitive mechanisms of synesthesia. Neuron, 48(3), 509-20. Retrieved from: http://www.cell.com/neuron/ fulltext/S0896-6273(05)00835-4

\section{АННОТАЦИЯ}

Статья посвящена изучению проблемы синестезии, которая проявляется в том, что раздражение в одной сенсорной или когнитивной системе ведет к автоматическому непроизвольному отклику в другой сенсорной системе.

В статье отражено продолжение исследования, результаты которого были опубликованы в предыдущей работе (Еливанова, Семушина, 2017), где мы описали статистически значимые цвета звуков/ букв алфавита и звуко-цветовые соответствия слов у синестетов. На следующем этапе исследования мы ставили целью изучить способность синестетов к звуко-цветовому и фоносемантическому анализу художественных поэтических текстов. Фоносемантика направление лингвистики, предметом которого является изучение звукоизобразительной системы языка. Оно основано на том, что звуки речи могут нести в себе свой особый самостоятельный смысл.

На первом этапе в опросе приняло участие 12 синестетов. Им было предложено для анализа стихотворение В. Хлебникова 
Sound-Color and Phono-Semantic Analysis of Literary Poetic Text...

"Кузнечик». Оказалось, что синестеты имеют неодинаковые возможности звуко-цветового анализа литературного поэтического текста, обусловленные индивидуальными и типовыми особенностями их синестезии. Двое (16,7\%) опрошенных респондентов, имеющие художественный тип высшей нервной деятельности и обладающие потенциалом понимания звукоизобразительной системы языка, оказались способны к фоносемантическому анализу поэтического текста на интуитивном уровне.

Затем мы предложили трём специально отобранным синестетам для анализа тексты стихотворений А. Блока, А. Белого и отрывок из стихотворения Edgar Allan Poе (в оригинале и в переводах трёх разных русских поэтов).

Результаты исследования показывают, что субъективный метод синестетов не точно совпадает с методом автоматического анализа, который основывается на значении частотности букв в тексте. Синестеты могут не всегда замечать цвет высоко частотных букв/ звуков, которые у них не одинаково значимы для восприятия окраски слов и текста в целом.

Особенности синестезии в сочетании с образным эмоциональным отражением звукоцвета художественных текстов позволяют синестетам интуитивно распознавать заложенную в текст фонетическими средствами языка мотивацию, исходящую от авторов стихотворений.

При индивидуальной вариативности синестетического восприятия текста фоносемантическая инвариантная универсальность создаётся в сознании за счёт синестемии и образного осмысления звукоцвета поэтических текстов.

Ключевые слова: синестезия, синестет, звуко-цветовые соответствия, фоносемантика, синестемия, буква, звук, ивет.

\section{Єліванова Марія. Особливості звуко-колірного і фоносемантичного аналізу поетичних текстів сінестетами}

\section{АНОТАЦІЯ}

Стаття присвячена вивченню проблеми синестезії, яка проявляється в тому, що роздратування в одній сенсорної або когнітивної системі призводить до автоматичного мимовільного відгуку в інший сенсорної системі.

У статті висвітлено продовження дослідження, результати якого були опубліковані в попередній роботі (Єліванова, Семушина 2017), у якому було описано статистично значущі кольори звуків / букв алфавіту й звуко-колірні відповідності слів у сінестетів. Було 
поставлено мету, що полягала у вивченні здатності сінестетів до звуко-колірного й фоносемантічного аналізу художніх поетичних текстів. Фоносемантика - напрямок лінгвістики, предметом якого $\epsilon$ вивчення звукоизображульної системи мови. Воно засноване на тому, що звуки мови можуть нести в собі свій особливий самостійний сенс.

На першому етапі в опитуванні взяло участь 12 сінестетов. Їм було запропоновано для аналізу вірш В. Хлєбнікова «Цвіркун». Виявилося, що сінестети мають неоднакові можливості звуко-колірного аналізу літературного поетичного тексту, зумовлені індивідуальними i типовими особливостями їх синестезії. Двоє $(16,7 \%)$ опитаних респондентів, які мають художній тип вищої нервової діяльності та володіють потенціалом розуміння звукозображувальної системи мови, виявилися здатними до фоносемантічного аналізу поетичного тексту на інтуїтивному рівні.

Далі нами було запропоноввано трьом спеціально відібраним сінестетам для аналізу тексти віршів О. Блока, С. Бєлого та уривок з віриа Edgar Allan Poе (в оригіналі і в перекладах трьох різних російських поетів). Результати дослідження показали, що суб'єктивний метод сінестетов неточно збігається з методом автоматичного аналізу, який грунтується на значенні частотності букв в тексті. Сінестети не завжди помічають колір високо частотних букв / звуків, які для них не однаково значущі для сприйняття забарвлення слів і тексту в цілому.

Особливості синестезії в поєднанні з образним емоційним відображенням звукокольору художніх текстів дозволяють сінестетам інтуїтивно розпізнавати закладену в текст фонетичними засобами мови мотивацію авторів віршів. У випадку індивідуальної варіативності сінестетичного сприйняття тексту фоносемантичного інваріантна універсальність створюється в свідомості за рахунок сінестеміі $і$ образного осмислення звукокольору поетичних текстів.

Ключові слова: синестезія, сінестет, звуко-колірні відповідності, фоносемантика, сінестемія, буква, звук, колір. 